\title{
Transcriptional Regulation of Human Polyomavirus JC: Evidence for a Functional Interaction between RelA (p65) and the Y-Box-Binding Protein, YB-1
}

\author{
GANESH V. RAJ, ${ }^{1,2}$ MAHMUT SAFAK, ${ }^{1}$ GENE H. MACDONALD,${ }^{3}$ AND KAMEL KHALILI ${ }^{1 *}$ \\ Department of Biochemistry and Molecular Biology, ${ }^{1}$ Molecular Neurovirology Section, Jefferson Institute of Molecular \\ Medicine, ${ }^{1}$ and Department of Microbiology and Immunology, Kimmel Cancer Institute, ${ }^{2}$ Thomas Jefferson \\ University, Philadelphia, Pennsylvania 19107, and Lineberger Comprehensive Cancer Center, University \\ of North Carolina, Chapel Hill, Chapel Hill, North Carolina $27599^{3}$
}

Received 16 June 1995/Accepted 21 May 1996

\begin{abstract}
The transcriptional control region of the human neurotropic polyomavirus JC virus contains a consensus NF-кB site which has been shown to enhance both basal and extracellular stimulus-induced levels of transcription of JC promoters. Here, we show that the expression of JC late promoter constructs containing the $\mathrm{NF}-\kappa \mathrm{B}$ site is decreased by cotransfection with the NF- $\mathrm{B} / \mathrm{rel}$ subunits, $\mathrm{p50}$ and $\mathrm{p52}$, but enhanced by the p65 subunit. However, JC promoter constructs lacking the NF-кB site were activated by $\mathrm{p52}$ and $\mathrm{p50}$ and repressed by p65. This antithetical response of the JC promoter mapped specifically to the $D$ domain, which is a target site for the cellular transcription factor, YB-1. Band shift studies indicated that YB-1 and p65 modulate each other's binding to DNA: YB-1 augments the affinity of p65 for the NF-kB site, while p65 reduces the binding of YB-1 to the D domain. Results from coimmunoprecipitation followed by Western blot (immunoblot) analysis suggest an in vivo interaction between $\mathrm{p65}$ and YB-1 in glial cells. Functionally, YB-1 appears to act synergistically with p65 to control transcription from the NF-кB site. A converse pattern is seen with the D domain, in which YB-1 acts synergistically with $\mathrm{p50}$ and $\mathrm{p52}$ to regulate transcription. p50 and p52 may function as transcriptional activators on the $D$ domain by removing the repressive effect of p65 on YB-1 binding to the $D$ domain. On the basis of these data, we propose a model in which $\mathrm{NF}-\kappa \mathrm{B} /$ rel subunits functionally interact with consensus NF-кB sites or YB-1-binding sites, with disparate effects on eukaryotic gene expression.
\end{abstract}

The NF- $\mathrm{B} / \mathrm{rel}$ family is a well-characterized example of inducible transcription factors that are involved in the regulation of immune and acute-phase responses at the transcriptional level (reviewed in references 4,40 , and 43 ). This family has at least five mammalian members, including p105-p50 (NF$\kappa \mathrm{B} 1$ ), p100-p52 (NF-кB2), c-rel, p65 (relA), and relB. These proteins share a common 300 -amino-acid region, the rel homology domain, which mediates DNA binding and proteinprotein interaction. The various subunits of this family interact via the rel homology domain to form several combinations of homo- or heterodimers. Each dimeric complex possesses a distinct binding affinity and specificity for DNA as well as a distinct transactivational potential $(15,24)$. Among the family members, p52 and p50 are poor transactivators that bind the NF- $\kappa \mathrm{B}$ site with a high affinity, while p65, c-rel and $\mathrm{relB}$ are strong transcriptional activators that exhibit a lower DNAbinding affinity (35-37).

Analysis of various cell lines and tissues indicates that p50, $\mathrm{p} 52$, and $\mathrm{relB}$ constitute the major components of $\mathrm{NF}-\mathrm{\kappa} \mathrm{B} / \mathrm{rel}$ present in nuclei of uninduced cells $(12,26)$. Other members, including c-rel, p65, p100, and p105, are confined largely to the cytoplasm in the uninduced cell (reviewed in references 4, 20, and 40). Upon induction, these cytoplasmic subunits rapidly translocate to the nucleus, where they dramatically alter dimeric combinations, specificity of DNA binding, and transactivational potency. In most cells, p50 homodimers are the

\footnotetext{
* Corresponding author. Mailing address: Department of Biochemistry and Molecular Biology, Molecular Neurovirology Section, Jefferson Institute of Molecular Medicine, Thomas Jefferson University, 233 S. Tenth St., Philadelphia, PA 19107. Phone: (215) 503-5534. Fax: (215) 923-5905.
}

predominant nuclear species in uninduced nuclei whereas the p50-p65 heterodimers form the major species in induced nuclei.

In addition to interfamily communication, $\mathrm{NF}-\kappa \mathrm{B} / \mathrm{rel}$ members interact directly with other proteins, including the IкB family (reviewed in references 5 and 17), the TATA-binding protein $(22,49), \mathrm{C} / \mathrm{EBP}$ family members (42), glucocorticoid receptor (33), NF-IL6 (25), fos/jun (41), and the human T-cell leukemia virus type 1 (HTLV-1) Tax protein (28). The ability of NF- $\mathrm{KB} / \mathrm{rel}$ subunits to functionally interact with these proteins tremendously expands the scope of NF- $\kappa \mathrm{B}$-mediated gene regulation.

The human neurotropic polyomavirus JC virus offers an excellent model system to study the effect of the inducible regulatory factors, especially those associated with the immune system, on transcription of eukaryotic genes. Seroepidemiological studies indicate that a majority of the population is subclinically infected with JC virus (reviewed in references 14, 27 , and 46). The virus is reactivated primarily in the context of chronic cellular immunosuppression, such as neoplasia, chronic diseases, chemotherapy, or, recently, AIDS (reviewed in reference 27). In such cases, JC virus progresses to lytic infection of oligodendroglia, the myelin-producing cells of the central nervous system and causes the demyelinating disease progressive multifocal leukoencephalopathy $(3,27,29)$. The reactivation of virus from latency is thought to be triggered by immunosuppressive states with their accompanying alterations in cytokine profile $(39,45)$.

Detailed analyses of the viral genome indicate that multiple regulatory modules within the transcriptional control region are responsible for coordinated expression of the viral genes. Figure 1 schematizes the structure of the JC promoter, which 


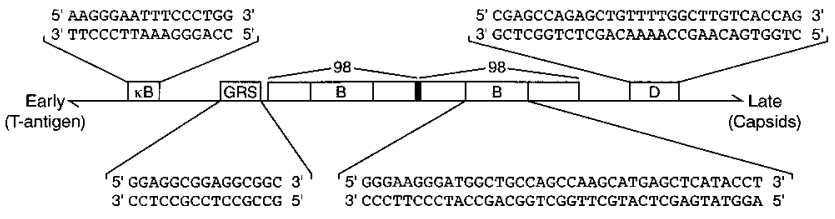

FIG. 1. Structure of the JC virus promoter. The schematic depicts the architecture of the JC transcriptional control region which lies between the transcription initiation start sites of the early and late genes. Specific sequences of the $\mathrm{NF}-\kappa \mathrm{B}$ site, the GG(A/C) repeat sequence, the B domain, and the D domain are detailed on either side of the schematic.

is located between the late and early coding regions. The viral promoter contains two characteristic 98-bp repeats. The B domain, previously identified as a potential determinant for viral tropism, is the target for several cellular proteins, including pur $\alpha, \mathrm{GF}-1$, and the Y-box-binding protein, YB-1. Outside the 98 -bp repeats, the $\mathrm{GG}(\mathrm{A} / \mathrm{C})$ repeat sequence represents a cytokine-responsive element that is the target for the previously characterized GBP-i (31). Further away from the 98-bp repeat lies a consensus NF- $\mathrm{kB}$ site $(27,32)$, whose sequence, $5^{\prime}$ GGGGAATTTCC 3', bears close homology (10 of 11 residues) to the human immunodeficiency virus (HIV) NF-кB site. However, previous observations suggested that distinct nucleoprotein complexes are formed between the JC NF-кB and the HIV NF-кB sites (32).

We have examined the role of the various $\mathrm{NF}-\kappa \mathrm{B} / \mathrm{rel}$ subunits and the effect of their homodimeric and heterodimeric complexes on the regulation of JC gene expression. In this report, we show that NF- $\mathrm{B} /$ rel subunits regulate the transcription of the JC promoter via two distinct sites: the consensus NF-кB-binding site and the D domain. The NF- $\mathrm{BB} / \mathrm{rel}$ subunits do not directly bind the $\mathrm{D}$ domain and appear to mediate their transactivation by a specific interaction of the p65 subunit with a cellular target for the D-domain, YB-1. The implications of this interaction in the context of $\mathrm{JC}$ virus and cellular gene regulation are discussed.

\section{MATERIALS AND METHODS}

Cells and tissue culture. All cell lines were maintained in either RPMI 1640 or Dulbecco's minimal essential medium supplemented with $10 \%$ (vol/vol) fetal calf serum (Gibco) and antibiotics (penicillin and streptomycin). U-87MG is a human glioblastoma cell line of astrocytic lineage (ATCC HTB14), which has been shown to support JC gene transcription and replication (2).

Transfection and CAT assays. Transient-transfection assays were carried out by the calcium phosphate method as previously described (19). Briefly, $5 \times 10^{5}$ cells were plated on a $60-\mathrm{mm}$ plate and grown overnight. At $3 \mathrm{~h}$ before transfection, the cells were fed with new growth medium. Transfections were carried out with the indicated amounts of reporter plasmids along with salmon sperm DNA to bring the total amount of DNA to $20 \mu \mathrm{g}$. Experiments were designed to be promoter controlled, with either Rous sarcoma virus (RSV) $\beta$-galactosidase (pRSV) or pCDNA3 (pCMV) plasmids added to equalize the total amounts of promoter in each reaction mixture. The precipitate was removed after 3 to $5 \mathrm{~h}$, and a glycerol shock was applied. At $48 \mathrm{~h}$ posttransfection, the cells were harvested and a crude protein extract was made by repeated cycles of freezing and thawing. Extracts were quantitated by the Bio-Rad Bradford assay, and equal amounts of protein were assayed for chloramphenicol acetyltransferase (CAT) activity (18). The fold transactivation was measured by scintillation counting of the spots cut from the thin-layer chromatography plate. Each experiment was repeated four or more times with different plasmid preparations.

Plasmids. The various deletion reporter constructs were made by using specific restriction enzymes, by performing exonuclease digestion of the linearized constructs, or by directionally cloning into the pBlcat 3 reporter plasmid (21). Cloning of the JC NF-кB site into this same reporter has also been described previously (32). Construction of the NF- $\mathrm{B}$ expression plasmids downstream of an RSV long terminal repeat was as described previously (30). Expression from the RSV promoter is significantly higher in the astrocytic U-87MG cells than is that from comparable amounts of a cytomegalovirus promoter (unpublished observations). The YB-1 expression plasmid downstream of a cytomegalovirus promoter and the histidine- $\mathrm{T}_{7}$-tagged $\mathrm{YB}-1$ expression plasmid (His- $\mathrm{T}_{7}$ YB-1)
(Invitrogen) have been described previously (21). All constructs were verified by sequencing and prepared with commercial kits (Qiagen).

Nuclear extract preparation. Nuclear extracts were prepared by a modification of the mini-extract protocol, as described by Schreiber et al. (38). These extracts were tested and found to exhibit a comparable binding activity to those prepared by the method of Dignam et al. (11). Briefly, $10^{6}$ cells were trypsinized, collected, washed once with medium and twice with phosphate-buffered saline, and transferred to Eppendorf tubes. The cells were then gently resuspended in cold hypotonic buffer [10 $\mathrm{mM} N$-2-hydroxyethylpiperazine- $N^{\prime}$-2-ethanesulfonic acid (HEPES; pH 7.9), $10 \mathrm{mM} \mathrm{KCl,} 0.1 \mathrm{mM}$ EDTA, $0.1 \mathrm{mM}$ ethylene glycol-bis( $\beta$ aminoethyl ether)- $N, N, N^{\prime}, N^{\prime}$-tetraacetic acid (EGTA), $1 \mathrm{mM}$ dithiothreitol 0.5 $\mathrm{mM}$ phenylmethylsulfonyl fluoride] and allowed to swell on ice. Nonidet P-40 was added to a final concentration of $0.5 \%$ (vol $/ \mathrm{vol}$ ), and lysis was accomplished by vigorous vortexing. Nuclei were pelleted by centrifugation at $8,000 \mathrm{rpm}$ (Eppendorf), resuspended in cold extraction buffer containing $20 \mathrm{mM}$ HEPES (pH 7.9), $0.4 \mathrm{M} \mathrm{NaCl}, 1 \mathrm{mM}$ EDTA, $1 \mathrm{mM}$ EGTA, $1 \mathrm{mM}$ dithiothreitol, and $1 \mathrm{mM}$ phenylmethylsulfonyl fluoride, and extracted at $4^{\circ} \mathrm{C}$ for $15 \mathrm{~min}$ on a rocking platform. The nuclear extract was centrifuged, and the supernatant was aliquoted and frozen at $-70^{\circ} \mathrm{C}$.

DNA-protein interactions. The oligonucleotides were prepared commercially by Oligos Etc., Guilford, Conn. The band shift assay was carried out essentially as described previously (31). The probes were end labeled with $\left[\gamma-{ }^{32} \mathrm{P}\right]$ ATP by using T4 polynucleotide kinase and then gel purified. Labeled probe $\left(10^{5} \mathrm{cpm}\right)$ was incubated with $5 \mu \mathrm{g}$ of nuclear extracts in a binding buffer containing $1.0 \mu \mathrm{g}$ of the nonspecific competitor poly(dI-dC), $5 \mathrm{mM}$ dGTP, $12 \mathrm{mM}$ HEPES ( $\mathrm{pH}$ 7.9), $4 \mathrm{mM}$ Tris ( $\mathrm{pH} 7.5$ ), $60 \mathrm{mM} \mathrm{KCl}, 5 \mathrm{mM} \mathrm{MgCl}_{2}$, and $0.8 \mathrm{mM}$ dithiothreitol. The reaction mixture was incubated at $4{ }^{\circ} \mathrm{C}$ for $30 \mathrm{~min}$ to allow assembly of DNA-protein complexes. The complexes were resolved by electrophoresis on a low-ionic strength $(0.5 \times$ Tris-borate-EDTA [TBE]) $6 \%$ native polyacrylamide gel. The gel was then dried, and the complexes were detected by autoradiography at $-70^{\circ} \mathrm{C}$ with an intensifying screen. For competition experiments, extracts were preincubated at $4^{\circ} \mathrm{C}$ with unlabeled competitor oligonucleotide for $10 \mathrm{~min}$ before addition of the probe. The nucleotide sequences of the DNA competitors are as follows:

D 5'-CGAGCCAGAGCTGTTTTGGCTTGTCACCAG-3' 3'-GCTCGGTCTCGACAAAACCGAACAGTGGTC-5'

B 5'-AgGtATGAGCTCATGCTTGGCTGGCAGCCATCCCTTCCC-3' 3'-TCCATACTCGAGTACGAACCGACCGTCGGTAGGGAAGGG-5'

B* 5'-GCTCATGCTTGGCTGGCAGCCAT-3' $3^{\prime}$-CGAGTACGAACCGACCGTCGGTA-5'

кB 5'-AAGGGAATTTCCCTGG-3' $3^{\prime}$-TTCCCTTAAAGGGACC-5

Bacterial protein purification. Bacterial YB-1 was prepared essentially as described previously (7). Basically, bacteria carrying the maltose-binding fusion protein were induced with isopropyl- $\beta$-D-thiogalactopyranoside (IPTG), and the protein was purified on amylose affinity columns (Invitrogen). The purified protein was then cleaved with factor Xa to remove the maltose-binding protein and extensively dialyzed against $1 \times$ gel retardation buffer.

The p50 and p65 proteins were prepared essentially as described previously (34). Briefly, mid-logarithmic-phase cultures (optical density at $595 \mathrm{~nm}, 0.4$ ) of Escherichia coli containing the pDS expression plasmid were induced by the addition of $1 \mathrm{M}$ IPTG for $4 \mathrm{~h}$. The cells were pelleted and lysed in $6 \mathrm{M}$ guanidine- $\mathrm{HCl}(\mathrm{pH} 8.0)$. The lysate was cleared by two rounds of centrifugation at $10,000 \times g$ for $20 \mathrm{~min}$ each, passed repeatedly through a 21 -gauge syringe needle, and adsorbed to a nickel chelate affinity column (probond resin; Invitrogen). The resin and the lysate were allowed to mix for $15 \mathrm{~min}$ at $4^{\circ} \mathrm{C}$ prior to gravity-driven separation. The column was repeatedly washed with $6 \mathrm{M}$ guanidine- $\mathrm{HCl}(\mathrm{pH} 8.0)$, after which gradual step elutions with lower-pH solutions were performed. Each fraction was individually collected after gravity separation. The purified proteins were then renatured slowly by dialysis against a 1,000-fold excess of $\mathrm{H}$ buffer (20 mM HEPES [pH 7.9], $0.2 \mathrm{mM}$ EDTA, $1 \mathrm{mM}$ dithiothreitol, $0.1 \%$ Nonidet P-40, $0.5 \mathrm{mM}$ phenylmethylsulfonyl fluoride) with $300 \mathrm{mM}$ $\mathrm{KCl}$ and gradual step declines in the guanidine- $\mathrm{HCl}$ concentrations $(4.5,3,2,1.5$, $1,0.5,0.25$, and $0 \mathrm{M}[\mathrm{pH} 8.0])$. Renatured fractions were then concentrated in a Centricon concentrator (molecular weight cutoff, 3,000) and assayed for quantity (Bradford assays), purity (sodium dodecyl sulfate-polyacrylamide gel electrophoresis, Coomassie blue staining), quality (Western blot analyses), and binding activity (gel shift analyses). Fractions with the highest purity, quality, and binding activity in good quantity were chosen for further analyses.

For in vivo interaction of p65 and YB-1, $5 \times 10^{5} \mathrm{U}-87 \mathrm{MG}$ cells were seeded in $10-\mathrm{mm}$-diameter plates and transfected with $10 \mu \mathrm{g}$ of p65 expression plasmid (pCMV-p65), $10 \mu \mathrm{g}$ of YB-1 expression plasmid (pHis- $\mathrm{T}_{7} \mathrm{YB}-1$ ), or $10 \mu \mathrm{g}$ of each plasmid expressing p65 and YB-1. The total amount of DNA was kept constant at $30 \mu \mathrm{g}$ by the addition of vector plasmid (pCMV) DNAs to each transfection mixture. After $36 \mathrm{~h}$, nuclear extracts were prepared and analyzed by Western blotting or immunoprecipitation followed by Western blotting. Antibody to His- $\mathrm{T}_{7}$ (Invitrogen) and p65 (Santa Cruz) were commercially prepared. 

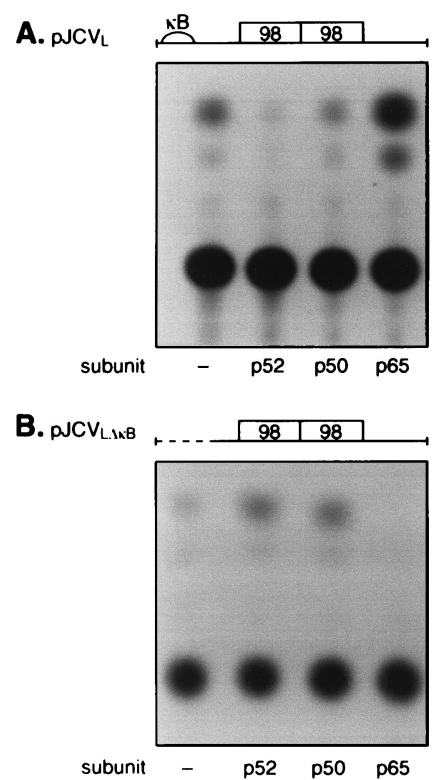

c.

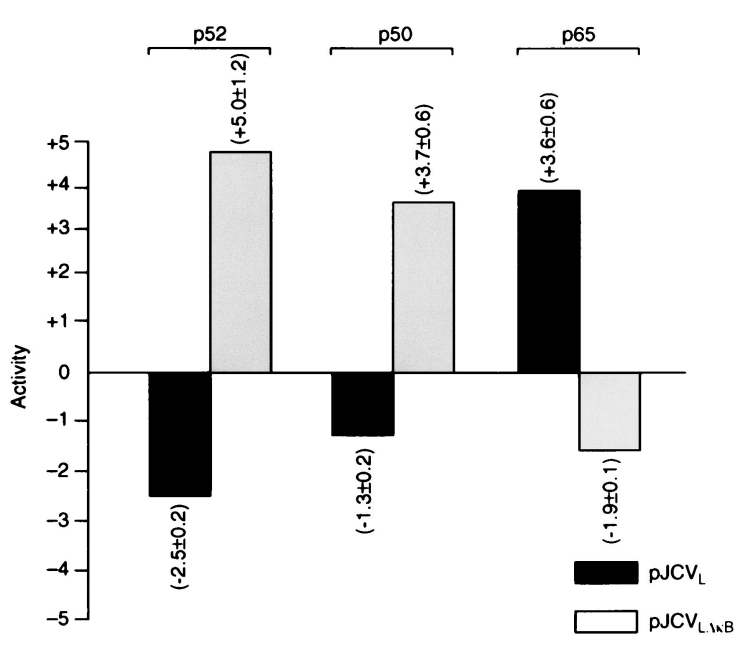

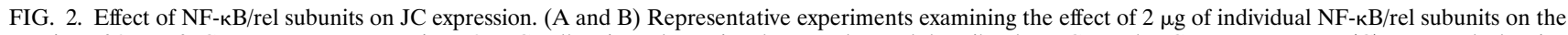
expression of $2 \mu \mathrm{g}$ of JC promoter constructs in U-87MG cells. Line schematics above each panel describe the pJCV and pJCV $\mathrm{V}_{\Delta \mathrm{B}}$ constructs. (C) Bar graph showing the average activity from three experiments of the JC promoter in the presence of NF- $\mathrm{B}$ subunits. Numbers above the bars represent the average fold activation with standard deviation.

Computer analysis. Comparative sequence analyses were performed with the software programs BESTFIT and SIGNALSCAN, transcription factor (TF) sites, and analysis of the eukaryotic promoter databases (GenBank).

\section{RESULTS}

Effect of NF-кB/rel subunits on JC expression. To examine the effect of various NF- $\mathrm{kB} / \mathrm{rel}$ subunits on JC gene expression, reporter constructs with either the full-length late promoter $\left(\mathrm{pJCV}_{\mathrm{L}}\right)$ or the late promoter with a deletion of the NF- $\mathrm{KB}$ site $\left(\mathrm{pJCV}_{\mathrm{L} \Delta \mathrm{\kappa}}\right)$ cloned upstream of the CAT gene were transiently transfected into the U-87MG human astrocytic cell line along with eukaryotic expression plasmids for individual NF$\kappa \mathrm{B} / \mathrm{rel}$ subunits.

p52 and p50 reproducibly and modestly (2.5- and 1.3-fold, respectively) repressed reporter activity from the $\mathrm{pJCV}_{\mathrm{L}}$ construct, whereas p65 increased the expression (3.6-fold) from the same construct (Fig. 2A and C). Under similar conditions, a control HIV-1 promoter construct containing the NF- $\mathrm{KB}$ site showed a similar responsiveness to the $\mathrm{NF}-\kappa \mathrm{B} / \mathrm{rel}$ subunits (unpublished observations). This functional similarity between the JC NF- $\mathrm{KB}$ and the HIV-1 NF- $\mathrm{KB}$ sites is expected, given the striking homology between the NF- $\mathrm{B}$ motifs of these two viruses.

Surprisingly, expression from the deletion construct $\left(\mathrm{pJCV}_{\mathrm{L} \Delta \kappa \mathrm{B}}\right.$ ) showed a reciprocal responsiveness to the NF-кB/ rel subunits. p52 and p50 significantly transactivated the $\mathrm{pJCV}_{\mathrm{L} \Delta \kappa \mathrm{B}}$ construct (5.0- and 3.7-fold, respectively), while p65 repressed transcription (1.9-fold) from the viral promoter (Fig. $2 \mathrm{~B}$ and $\mathrm{C}$ ). This effect is unique for $\mathrm{JC}$, since the HIV-1 constructs lacking the $\mathrm{NF}-\kappa \mathrm{B}$ site were unresponsive to the $\mathrm{NF}-\kappa \mathrm{B} / \mathrm{rel}$ subunits (unpublished observations; also shown in reference 30). Additionally, JC promoter constructs with mutations in the NF-кB site were transactivated by p50 and p52 and repressed by p65 (27a).

Since NF-кB is also regulated by subcellular compartmentalization, nuclear and cytoplasmic extracts from U-87MG cells transiently transfected with various subunits were examined by mobility shift assays for nuclear enrichment of the transfected subunits. A dramatic increase in binding to the NF- $\mathrm{kB}$ site in the nuclear extracts and a more subtle increase in binding in the cytoplasmic extracts confirmed previous observations that the transfected subunits are largely nuclear (data not shown).

The data suggest a duality of NF- $\mathrm{B} /$ rel-mediated effects on the $\mathrm{pJCV}_{\mathrm{L}}$ promoter activity. The presence of the NF- $\mathrm{B}$ site on the JC promoter renders a classic portrait of p50 and p52 as repressors and p65 as an activator. The absence of the NF-кB site on the JC promoter inverts the picture with p50 and p52 as activators and $\mathrm{p} 65$ as a repressor.

Identification of $\mathrm{NF}-\mathbf{\kappa} \mathbf{B} /$ rel-responsive regions. Deletion analyses were performed to identify the NF- $\mathrm{B} /$ rel-responsive regions on the JC promoter. Sequential deletions through the first or second 98-bp repeat pointed to the existence of a more downstream responsive region. The level of activation by p50 and p52 appeared to be increased (compare the average 10fold activation seen with the $\mathrm{pJCV}_{\Delta 19}$ construct with the 4- to 5 -fold activation seen with the larger constructs) and the repression by 065 appeared to be decreased with the sequential deletions. This is largely a consequence of progressively lower basal activity of the smaller reporter constructs, which may tend to magnify the activation and minimize the repression by the NF- $\mathrm{KB} / \mathrm{rel}$ subunits. Normalization of basal activity with higher concentrations of the smaller reporter constructs tended to reproduce the changes with the larger constructs.

Expression from the smallest deletion construct, pCAT-D (formerly called $\mathrm{pJCV}_{\mathrm{L} \Delta 11}$ ), was augmented (8- to 10 -fold) by p52/p50 and attenuated (2-fold) by p65. The basal reporter construct, pCAT, alone showed no response to the subunits, potentially identifying sequences between +240 and +270 on the viral genome as an NF- $\mathrm{B} /$ rel-responsive region. This responsive region has previously been characterized as the $\mathrm{D}$ domain (Fig. 1). The pJCV ${ }_{-\triangle \mathrm{D} \Delta \kappa \mathrm{B}}$ construct, which lacks both the NF- $\mathrm{BB}$ site and the D domain, was unresponsive to the $\mathrm{NF}-\kappa \mathrm{B} /$ rel subunits (Fig. 3). These data identify the D domain as the second $\mathrm{NF}-\mathrm{\kappa} B /$ rel-responsive region on the JC pro- 


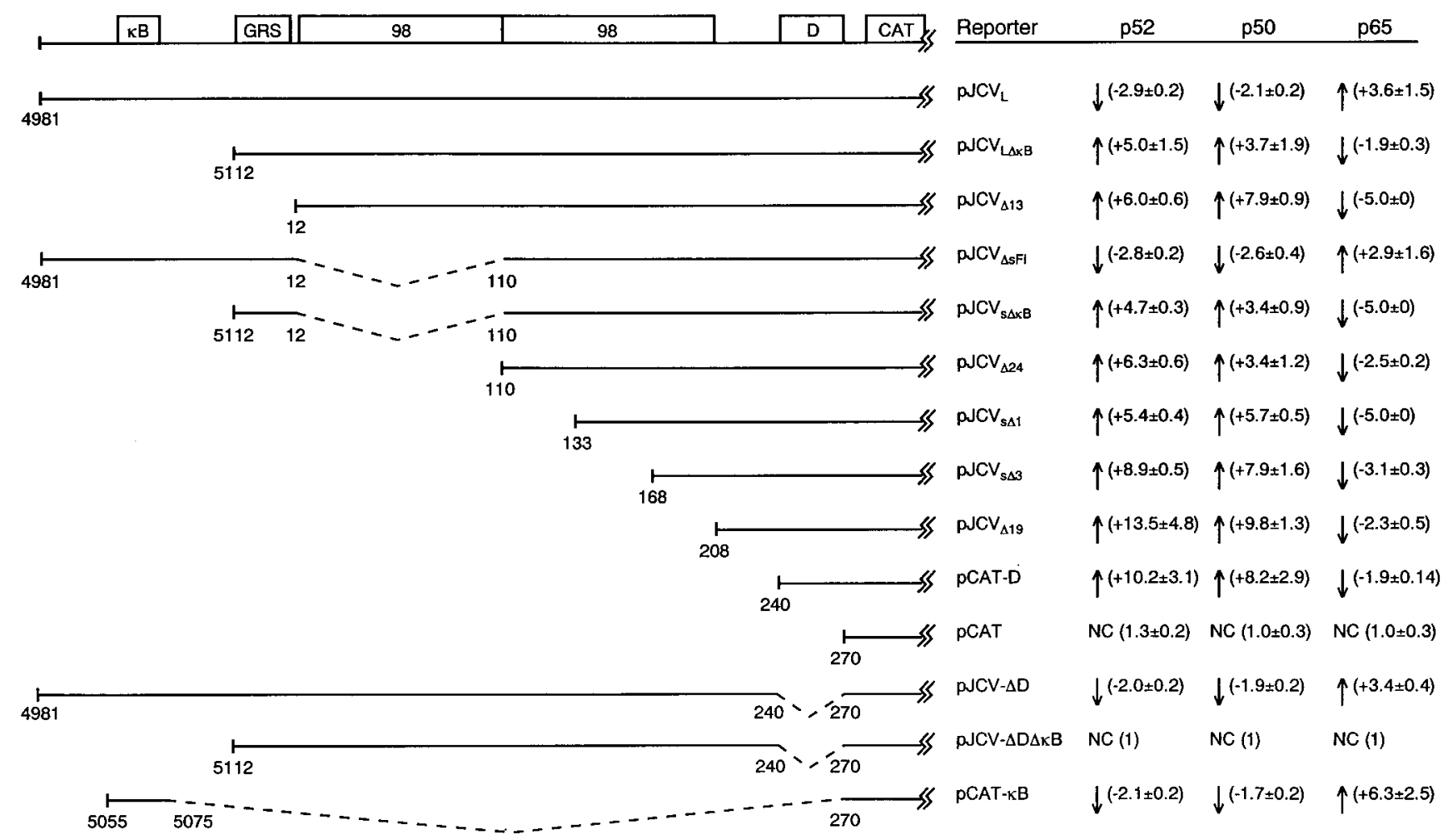

FIG. 3. Identification of the NF-кB-responsive subunits on the JC promoter. The organizational structure of the various JC promoter constructs, with numbers that reflect positions on the viral genome, is given on the left. The designations adjacent to the map represent the name of each plasmid reporter construct. The panel on the right portrays the effect of $2 \mu \mathrm{g}$ of the various NF- $\mathrm{BB} / \mathrm{rel}$ subunits on $2 \mu \mathrm{g}$ of each reporter construct in U-87MG cells, with arrows depicting the overall effect and numbers in parentheses showing the average fold effect with standard deviation. The numbers are all standardized to the basal level of expression of each reporter construct. NC, no change.

moter. Importantly, the NF-кB/rel subunits were able to modulate expression from the $\mathrm{D}$ domain only in the absence of a functional NF- $\mathrm{\kappa B}$ site on the JC viral promoter.

$\mathrm{pJCV}_{-\Delta \mathrm{D}}$, a full-length construct lacking the $\mathrm{D}$ domain, behaved like $\mathrm{pJCV}_{\mathrm{L}}$ with activation by $\mathrm{p} 65$ and $\mathrm{p} 50 / \mathrm{p} 52$, respectively. Furthermore, pCAT-кB, which contains a minimal promoter with only the NF-кB site, responded to p65 and p50/p52 in a manner similar to $\mathrm{pJCV}_{\mathrm{L}}$. It appears that the absence or presence of the $\mathrm{D}$ domain has no influence on the effect of the NF- $\mathrm{B} / \mathrm{rel}$ subunits on the expression from a $\mathrm{NF}-\kappa \mathrm{B}$ site.

These data point to the existence of two NF- $\mathrm{BB} /$ rel-responsive regions within the JC viral promoter: the NF- $\kappa B$ site and the $\mathrm{D}$ domain. These sites show a curious reciprocal regulation by NF- $\mathrm{NB} / \mathrm{rel}$ subunits, with activation by $\mathrm{p} 65$ and repression by p50/p52 of the transcription from the NF-кB site and activation by $\mathrm{p} 50 / \mathrm{p} 52$ and repression by $\mathrm{p} 65$ of the transcription from the D domain.

Interaction between $\mathbf{N F}-\mathbf{\kappa} B /$ rel subunits. Cotransfection analyses with dimeric combinations of the NF-кB/rel subunits were performed to evaluate their functional interactions on the D domain. Titration of increasing concentrations of p65 gradually squelched the p52-mediated activation of transcription from the pCAT-D construct (Fig. 4A, compare lanes 2 and 3 with lanes 5 and 6, lanes 8 and 9, and lanes 11 and 12). Similar experiments indicated that p50 and p52 can overcome the transcriptional effect of p65 on promoters driven by either the $\mathrm{NF}-\kappa \mathrm{B}$ site or the D domain (data not shown). Taken together, these data suggest that the NF- $\mathrm{B} / \mathrm{rel}$ subunits $\mathrm{p} 50 / 52$ and $\mathrm{p} 65$ are mutually antagonistic in terms of their transcriptional activity from either the D domain or the NF-кB site.

Nuclear proteins that bind to the $D$ domain. The identification of the $\mathrm{D}$ domain as a potential NF- $\mathrm{B} /$ rel-responsive region on $\mathrm{pJCV}_{\mathrm{L}}$ led to investigation of the interaction between the NF- $\mathrm{kB} / \mathrm{rel}$ proteins and the D domain. Computeraided analysis indicated no similarity between optimal binding sites for various $\mathrm{NF}-\kappa \mathrm{B} / \mathrm{rel}$ dimers (24) and the D domain. Competition gel shift analyses and antibody supershift experiments revealed no evidence for the presence of $\mathrm{NF}-\kappa \mathrm{B} / \mathrm{rel}$ subunits in nucleoprotein complexes formed with the D-domain oligonucleotide (unpublished data). Thus, we suspected that the interplay between NF-кB subunits and other cellular proteins may have been responsible for the observed regulatory action of NF- $\mathrm{kB}$ on the JC D domain. Computer-aided analyses of the $\mathrm{D}$ domain revealed no potential binding sites for TATA-binding protein, C/EBP, SP1, SRF, GR, NF-IL6, and other identified partners for NF-кB/rel. However, these analyses indicated a high degree of similarity between the $\mathrm{D}$ domain and another region on the $\mathrm{JC}$ promoter, the $\mathrm{B}$ domain, which is the binding site for the Y-box family member the YB-1 transcription factor $(9,21,23,44,48)$. To examine the importance of this similarity, competition DNA-binding studies were carried out with glial nuclear extracts and various oligonucleotide competitors (Fig. 5). The homologous competitor (D), as well as competitors from the B domain of JC virus, were able to compete for the binding of some nucleoprotein complexes to the D domain (Fig. 5A, lanes 2 and 3). However, neither a variant of the $\mathrm{B}$ domain, $\mathrm{B}^{*}$, which lacks the CT-rich se- 
A.

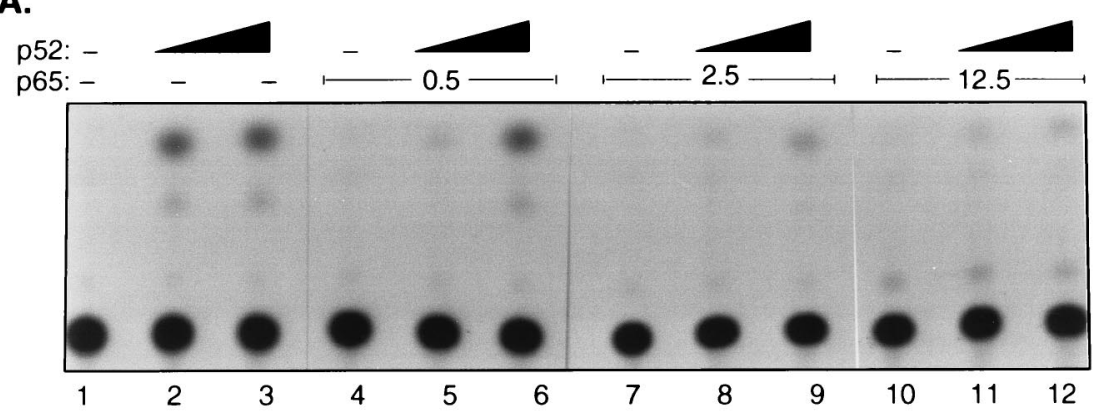

B.

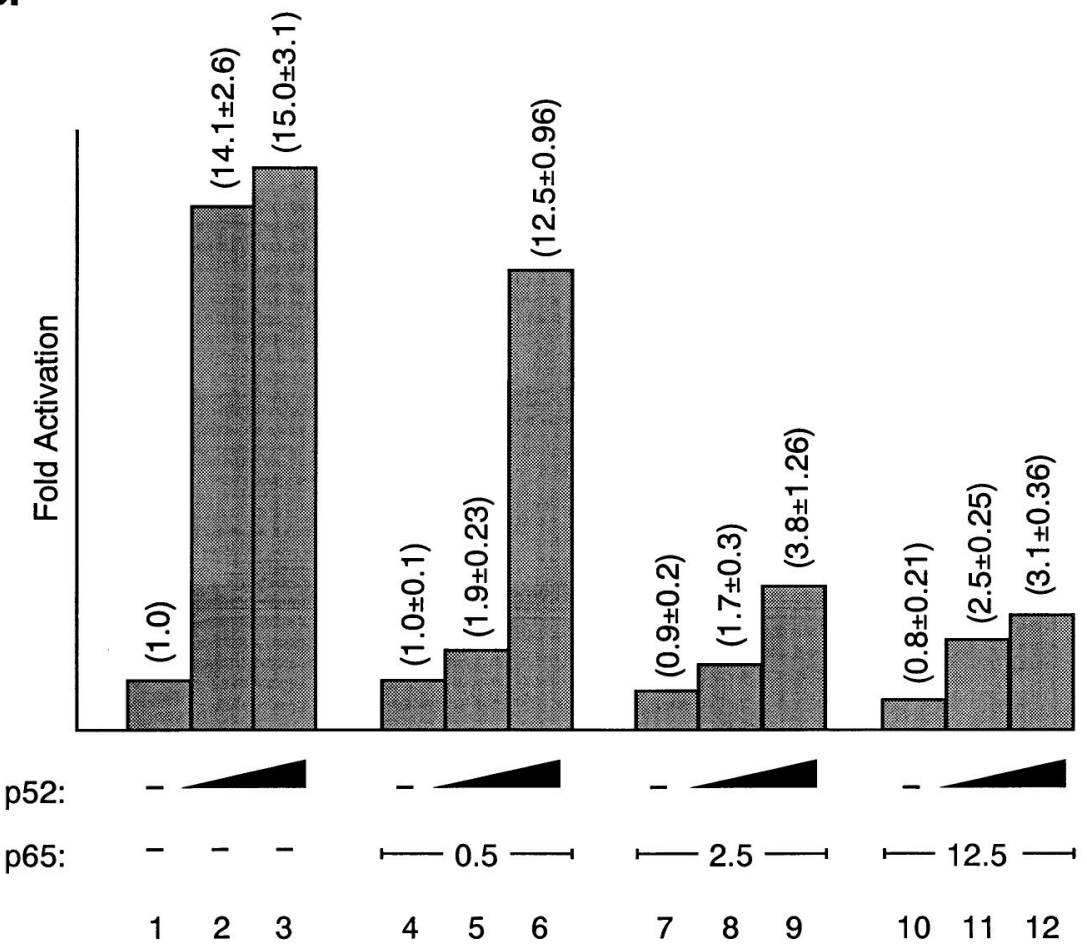

FIG. 4. Dose-dependent effect of NF- $\mathrm{kB} / \mathrm{rel}$ subunits on the pCAT-D construct. The effect of increasing concentrations $(0,0.5$, and $2.5 \mu \mathrm{g})$ of pRSV-p52 on the expression of the pCAT-D construct $(1 \mu \mathrm{g})$ in the presence of increasing concentrations of pRSV-p65 (0 $\mu \mathrm{g}$ [lanes 1 to 3 ] $0.5 \mu \mathrm{g}$ [lanes 4 to 6], $2.5 \mu \mathrm{g}$ [lanes 7 to 9], and $12.5 \mu \mathrm{g}$ [lanes 10 to 12]) in U-87MG cells was examined. The overall amounts of pRSV in each transfection were brought to $15 \mu \mathrm{g}$ with RSV- $\beta$ gal plasmid. (A) Representative experiment; (B) average activation observed over several experiments.

quences, nor the NF-кB-binding site had an effect on the nucleoprotein complexes (lanes 4 and 5). Binding of YB-1 to the $\mathrm{D}$ domain was examined by supershift analysis, and the results suggested the presence of YB-1 in the more slowly migrating complex (31a). The reported molecular mass of YB-1 (37 to $42 \mathrm{kDa}$ ) (47) is in agreement with the previously reported $43-\mathrm{kDa}$ nucleoprotein complex detected on the $\mathrm{D}$ domain (1).

Next, direct interaction of YB-1 with the D domain was further investigated by using purified, prokaryotically expressed YB-1 in a competition band shift assay. YB-1 binds the $\mathrm{D}$ domain under native conditions with a sequence requirement similar to that of the more slowly migrating complex in the U-87MG nuclear extract, as evidenced by competition analysis (Fig. 5B). Oligonucleotides from the B domain efficiently competed for YB-1 binding to the D domain (Fig. 5B, lane 2), while the variant of the B sequence, $B^{*}$, and the NF- $\mathrm{B}$ site did not (lanes 3 and 4). We attempted to identify specific nucleotides on the D domain that were in contact with YB-1. Methylation interference assay did not show any protection over $\mathrm{G}$ residues of the $\mathrm{D}$ domain (unpublished observations). This result is not surprising, given the nature of YB-1 as a CT-tract binding protein.

Taken together, these data provide compelling evidence that YB-1 interacts with the D domain. The identity of other Ddomain-binding proteins is of interest, in terms of their potential interaction with YB-1 and the NF- $\mathrm{KB} / \mathrm{rel}$ members.

Interaction of YB-1 and the NF- $\mathrm{NB} /$ rel subunits with the $D$ domain. We examined the potential interactions between YB-1 and the NF- $\mathrm{B}$ /rel members in mobility shift assays with highly purified prokaryotically produced proteins. As shown in Fig. 6A, addition of p50 to the binding-reaction mixture did not significantly affect YB-1 binding to the D domain even at the highest concentration (compare lane 1 with lanes 2 to 4 ). 
A.

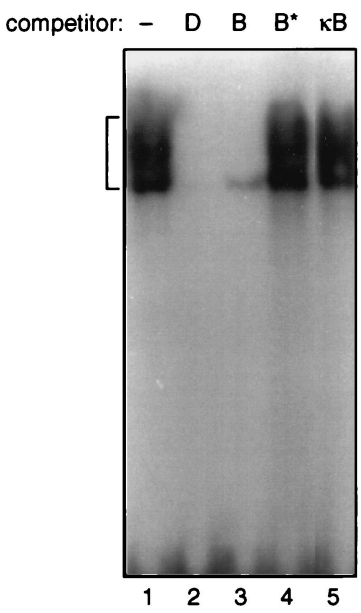

B.

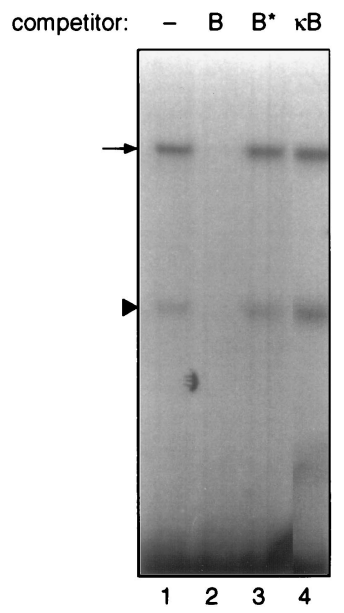

FIG. 5. YB-1 binds to the D domain. (A) Competition mobility shift assays were performed with nuclear extracts from U-87MG cells and labeled D-domain probe in either the absence (lane 1) or presence of a 1,000-fold excess of cold unlabeled oligonucleotides derived from the homologous $\mathrm{D}$ domain (lane 2), the B domain (lane 3), a mutant variant of the B domain, B* (lane 4), and the NF-кB site (lane 5). (B) A similarly organized competition experiment with bacterially produced YB-1.

Furthermore, p50 was unable to bind the D domain (lane 5). On the other hand, at higher concentrations, p65 was able to disrupt binding of YB-1 to the D domain (Fig. 6B, compare lane 1 with lane 4). This disruptive effect of p65 is specific for YB-1, because it showed no effect on the binding of another DNA-binding protein, GF-1, to the D domain (unpublished observations). At high concentrations, the highly purified p65 was able to bind, albeit weakly, the D domain (Fig. 6B, lane 5). This interaction, however was not detected in the presence of YB-1 (compare lane 5 with lane 4). It should be noted that the heterodimer p50-p65 complexes were able to decrease the binding of YB-1 to the D domain, although not as efficiently as p65 did. Again, no complexes were detected between p50/p65 and the $\mathrm{D}$ domain (data not shown).

In parallel studies, increasing concentrations of YB-1 had virtually no effect on p50 binding to the NF-кB probe (Fig. $6 \mathrm{C}$, compare lane 1 with lanes 2 to 4 ). YB-1 by itself was unable to bind to the $\mathrm{NF}-\kappa \mathrm{B}$ site (lane 5). Interestingly, addition of increasing concentrations of YB-1 to the binding-reaction mixture dramatically increased the association of p65 and the NF- $\mathrm{B}$ probe (Fig. 6D, compare lane 1 with lanes 2 to 4 ). Similar concentrations of either a control bacterial protein, i.e., maltose-binding protein, or GF-1 showed no effect on p65 binding (data not shown).

Taken together, these data suggest that p65 and YB-1 have the ability to influence each other's binding ability to their respective targets. p65 diminishes YB-1 binding to the D domain, and, in turn, YB-1 increases p65 binding to NF-кB. The reciprocal nature of the interaction between YB-1 and p65 implies direct protein-protein contact.

Preliminary far Western data obtained with highly purified p65 and YB-1 suggested a direct and specific interaction between YB-1 and p65 but not between YB-1 and p50 (31a). To evaluate the interaction between $\mathrm{p} 65$ and YB-1 in vivo, expression plasmids producing histidine-tagged YB-1 (His- $\left.\mathrm{T}_{7} \mathrm{YB}-1\right)$ and p65 (pCMV-p65) were constructed and introduced into U-87MG glial cells. Nuclear extracts were examined by immu-

A.

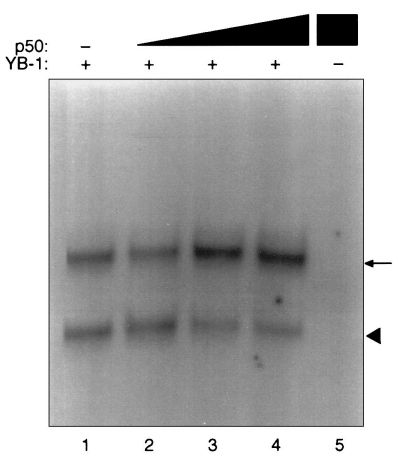

C.

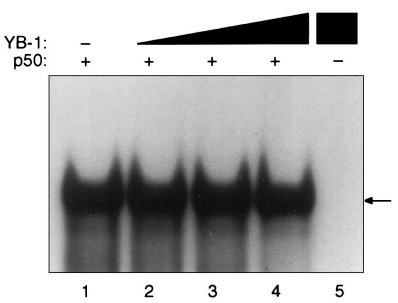

D.

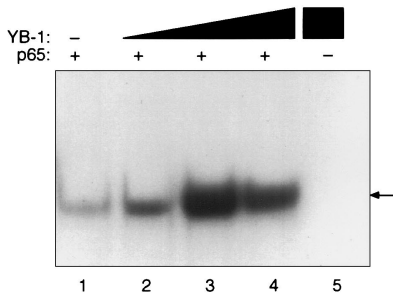

FIG. 6. Interaction between $\mathrm{YB}-1$ and $\mathrm{NF}-\mathrm{\kappa B} / \mathrm{rel}$ subunits. Mobility shift assays were performed with purified prokaryotically expressed proteins and labeled probes from either the D domain (A and B) or the NF- $\mathrm{B}$ site $(\mathrm{C}$ and $\mathrm{D})$. Increasing concentrations $(10,100$, and $1,000 \mathrm{ng}$ ) of purified p50 (A, lanes 2 to 4) or purified p65 (B, lanes 2 to 4 ) were incubated with $10 \mathrm{ng}$ of purified YB-1 prior to the addition of the D-domain probe. The binding activities of these proteins individually to the D domain can be seen for $10 \mathrm{ng}$ of YB-1 (A and B, lanes 1), $1,000 \mathrm{ng}$ of $\mathrm{p} 50$ (A, lane 5), and $1,000 \mathrm{ng}$ of $\mathrm{p} 65$ (B, lane 5). In the reciprocal experiments, increasing concentrations of YB-1 (10, 100 and 1,000 ng) were incubated with $1 \mathrm{ng}$ of either purified p50 (C, lanes 2 to 4$)$ or p65 (D, lanes 2 to 4 ). The binding activities of these proteins individually to the NF- $\mathrm{BB}$ site can be seen for $1 \mathrm{ng}$ of p50 (C, lane 1), $1 \mathrm{ng}$ of p65 (D, lane 1), or 1,000 ng of YB-1 $(\mathrm{C}$ and $\mathrm{D}$, lanes 5$)$. Overall protein amounts and volumes per reaction were normalized with bovine serum albumin

noprecipitation Western blot analyses for the level of expression of the proteins and their association with each other. Western blot analyses indicate detectable levels of nuclear expression of a $65-\mathrm{kDa}$ protein species with anti-p65 antibody (Fig. 7A, lane 1) and a 40-kDa protein species (corresponding to the expected size of the YB-1 fusion protein) with the anti-His- $\mathrm{T}_{7}$ antibody (Fig. 7C, lane 1). As expected, the $65-\mathrm{kDa}$ protein species was immunoprecipitated by anti-p65 antibody (Fig. 7A, compare lane 1 with lane 3). A similar 65-kDa protein species was detected in the anti-p65 probe of the Western blot of the immunocomplex pulled down with anti-His- $\mathrm{T}_{7}$ antibody (Fig. 7B, lane 3). This result suggests that p65 and YB-1 interact with each other in the transfected glial cells. In the reciprocal experiment, a $40-\mathrm{kDa}$ protein species can be detected by the anti-His- $\mathrm{T}_{7}$ Western blot of the immunocomplex pulled down with the anti-p65 antibody (Fig. 7C, compare lane 1 with lane 3). Taken together, these observations strongly suggest that YB-1 and p65 bind to each other in vivo.

Functional interaction between YB-1 and NF-кB. Transienttransfection assays were performed to examine the biological relevance of YB-1 and p65 interaction, with regard to the regulation of $\mathrm{JC}$ promoter activity from both the $\mathrm{NF}-\kappa \mathrm{B}$ site and the $\mathrm{D}$ domain.

YB-1 was able to activate transcription from a minimal promoter containing the JC NF-кB site (pCAT-кB) (Fig. 8A, lane 1 ; Fig. $8 \mathrm{~B}$, lane 2 ). The ability of $\mathrm{YB}-1$ to activate transcription 

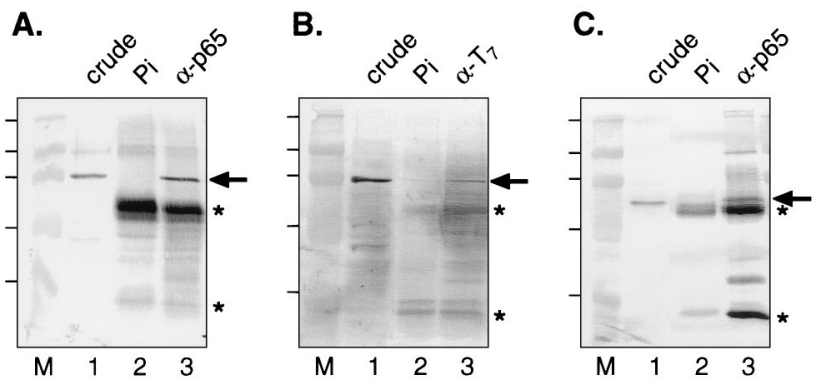

FIG. 7. Interaction between YB-1 and p65 in glial cells. U-87MG cells were transfected with His- $\mathrm{T}_{7}$ YB-1 and/or p65, alone or together, by the calcium phosphate precipitation method. After $36 \mathrm{~h}$, nuclear extracts were prepared and analyzed by Western blot assay either directly (lanes 1 ) or after being immunoprecipitated with preimmune serum (lanes 2) or specific antibodies (lanes 3) as indicated above the lanes. (A and B) Blots were reacted with anti-p65 antibody (Santa Cruz); (C) blot was incubated with $\mathrm{His} \mathrm{T}_{7}$ antibody (Invitrogen). The arrows in panels $\mathrm{A}$ and $\mathrm{B}$ depict the position of the band corresponding to p65; the arrow in panel $\mathrm{C}$ points to the $40-\mathrm{kDa}$ YB- 1 fusion protein. The asterisks indicate immunoglobulin $\mathrm{G}$ heavy and light chains from immunoprecipitation. Lane M, protein high-molecular-weight marker.

from pCAT-кB was dependent upon the presence of a functional NF- $\mathrm{BB}$ site, because mutations in the NF- $\mathrm{BB}$ site abolished the transactivational ability of YB-1 (data not shown). Cotransfection assays indicated that YB-1 attenuated the p50and p52-mediated repression of pCAT-кB (Fig. 8A, compare lane 3 with lanes 5, 7, and 9). In contrast, YB-1 synergistically enhanced the p65-mediated transcriptional activation of pCAT-кB (compare lane 11 with lane 13). In the antisense orientation, YB-1 decreased the ability of p65 to activate transcription from the NF- $\kappa \mathrm{B}$ site (compare lane 11 with lane 16). These observations suggest that YB-1/p65 interaction may be relevant for both the basal and p65-mediated transactivation of the NF- $\kappa \mathrm{B}$ site.

YB-1 exhibited no effect on transcription from a minimal promoter containing the D domain (pCAT-D) (Fig. 8A, lane 2; Fig. 8B, lane 1). YB-1 did not affect p65-mediated repression from the D domain (Fig. 8A, compare lane 12 with lane 14). One explanation is that the very low transcriptional activity observed in the presence of p65 may mask any corepressive effect of YB-1. In contrast, YB-1 enhanced p50/52-mediated transactivation of pCAT-D (compare lane 4 with lane 6 , and lane 8 with lane 10). Again, in the antisense orientation, YB-1 overcame p50-mediated activation from the D domain (compare lane 8 with lane 18). These observations suggest that YB-1 is involved in the transcriptional activation from the D domain by $\mathrm{p} 50 / 52$.

In light of the demonstrated physical interaction between p65 and YB-1, additional cotransfection experiments were performed to examine the functional interplay between p50 and YB-1. The ability of YB-1 to activate expression from the NF-кB site was overcome by titration of increasing concentrations of p50 (Fig. 8B, compare lanes 6, 10, and 14). This effect is more pronounced than the repressive effect of p50 on the basal expression from the pCAT-кB promoter (compare lanes 6, 10, and 14 with lanes 4, 8, and 12, respectively). Since p50-p65 complexes do not interact well with YB-1, these observations allow speculation that p50 functions to sequester p65 from interaction with YB-1 and thus decrease the net transcriptional activity of YB-1 from an NF- $\mathrm{BB}$ site.

The expression of pCAT-D mediated by p50 was also more dramatic in the presence of YB-1 (Fig. 8B, compare lanes 5, 9, and 13 with lanes 3,7 , and 11). Perhaps p50 functions to
A.

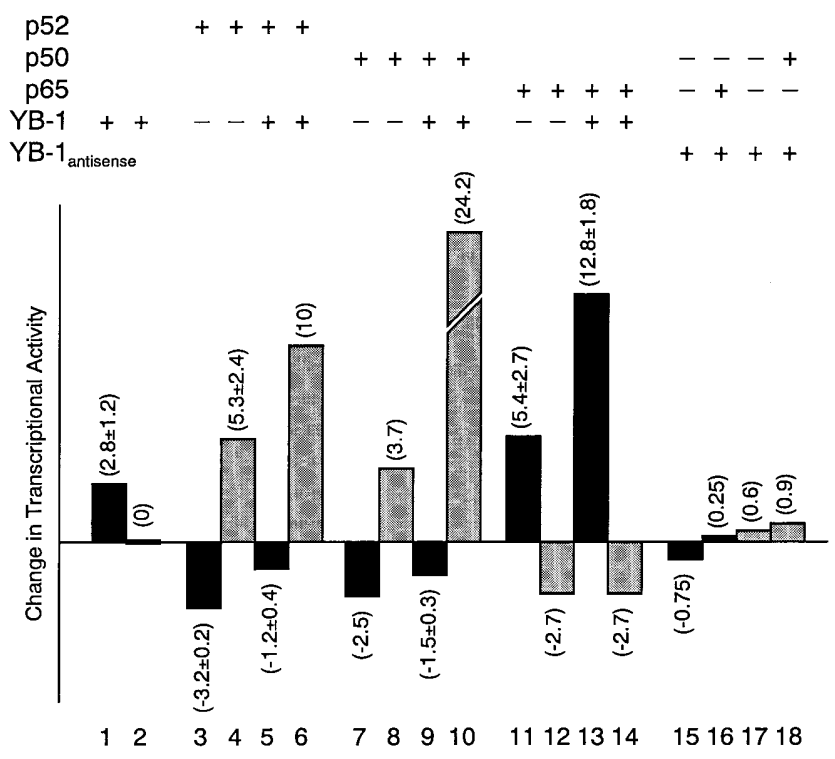

B.

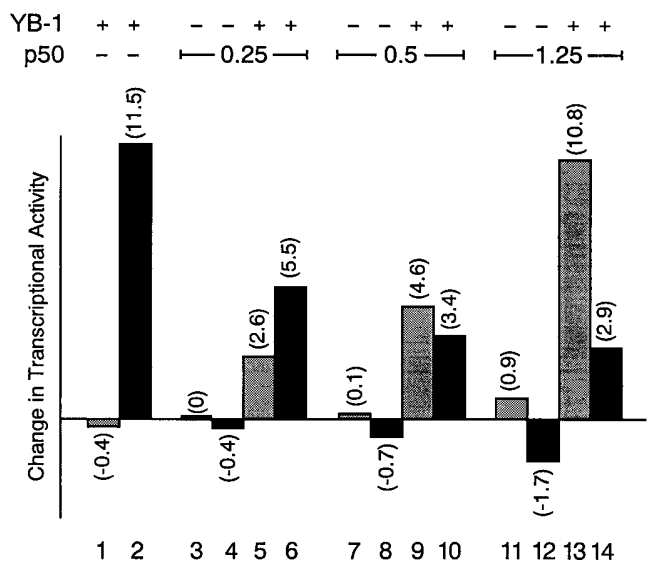

FIG. 8. Functional interaction between YB-1 and the NF- $\mathrm{B} / \mathrm{rel}$ subunits. (A) The effect of $2 \mu \mathrm{g}$ of pRSV p52 (lanes 3 to 6), pRSV p50 (lanes 7 to 10), and pRSV p65 (lanes 11 to 14) on the expression from $1 \mu \mathrm{g}$ of the indicated reporter plasmids in the presence of $2.5 \mu \mathrm{g}$ of pCMV (lanes 3 and 4, 7 and 8 , and 11 and 12) or $2.5 \mu \mathrm{g}$ of pCMV YB-1 (lanes 5 and 6,9 and 10 , and 13 and 14) in U-87MG cells was examined. The effect of $2.5 \mu \mathrm{g}$ of pCMV YB-1 alone is shown (lanes 1 and 2). The change in transcriptional activity measures the change in the fold activation or repression over basal, which is defined as the effect of $2.5 \mu \mathrm{g}$ of pCMV on the reporter construct. The effect of $2.5 \mu \mathrm{g}$ of pCMV antisense YB-1 either alone (lanes 15 and 17) or in the presence of p50 (lane 16) or p65 (lane 18) is also depicted. (B) The effect of $12.5 \mu \mathrm{g}$ of pCMV YB-1 on the expression from $1 \mu \mathrm{g}$ of the indicated reporter plasmids in the presence of increasing but suboptimal concentrations of pRSVp50 $(0 \mu \mathrm{g}$ [lanes 1 and 2], $0.25 \mu \mathrm{g}$ [lanes 5 and 6], $0.5 \mu \mathrm{g}$ [lanes 9 and 10], and $1.25 \mu \mathrm{g}$ [lanes 13 and 14]) in U-87MG cells was examined. The effect of pRSVp50 alone $(0.25 \mu \mathrm{g}$ [lanes 3 and 4 ], $0.5 \mu \mathrm{g}$ [lanes 7 and 8], and $1.25 \mu \mathrm{g}$ [lanes 11 and 12]) is also shown. Symbols: pCAT-кB; \%, pCAT-D.

sequester p65 from YB-1 and the D domain, allowing YB-1 to bind to and activate transcription from the $\mathrm{D}$ domain.

To further evaluate these hypotheses, we used mutant versions of NF- $\mathrm{KB} / \mathrm{rel}$ proteins. The inactive full-length versions of p50 and p52, i.e., p105 and p100, respectively, were unable to 
A.

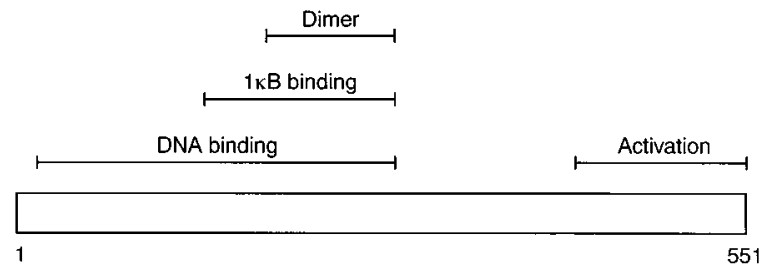

B.

\begin{tabular}{|c|c|c|c|}
\hline \multirow{2}{*}{\multicolumn{2}{|c|}{ p65 Construc }} & \multicolumn{2}{|c|}{ Reporter } \\
\hline & & PCAT-D & pCAT-kB \\
\hline & |-551 & $(0.9)$ & $\uparrow(20.5)$ \\
\hline 2. & $1-450$ & (1.3) & $(3.1)$ \\
\hline & $1-312$ & (1.6) & $(0.9)$ \\
\hline 4. & I-298 & $\uparrow^{(3.6)}$ & $(0.8)$ \\
\hline
\end{tabular}

C.

\begin{tabular}{|c|c|c|c|}
\hline \multicolumn{4}{|c|}{ Reporter } \\
\hline \multicolumn{2}{|c|}{ PCAT-D } & \multicolumn{2}{|c|}{ рСAT-кB } \\
\hline -Yb-1 & $+Y b-1$ & $-Y b-1$ & $+Y b-1$ \\
\hline 0.9 & 1 & 1 & 3.6 \\
\hline 0.9 & 3.4 & 0.3 & 0.3 \\
\hline
\end{tabular}

FIG. 9. Functional interaction between YB-1 and mutant p65 constructs. (A) A schematic depicting the functional domain of p65 previously dissected (16). (B) Effect of $5 \mu \mathrm{g}$ of pCMV-p65 constructs on the expression of $1 \mu \mathrm{g}$ of indicated reporter plasmid. The overall effect and numbers in parentheses show fold effect on transcription of the reporter constructs. The numbers are normalized to the basal level of expression of each reporter construct. (C) Representative experiment showing the fold effect of $2 \mu \mathrm{g}$ of pCMV-p65 constructs on transcription from $2.5 \mu \mathrm{g}$ of pCAT-D and $1 \mu \mathrm{g}$ of pCAT-KB reporters in the absence or presence of $5 \mu \mathrm{g}$ of pCMV-YB-1.

affect transcription from promoters driven by the NF- $\mathrm{B}$ site or the YB-1-binding sites on the D domain or the B domain (31a).

In an attempt to further elucidate the effect of the functional interaction between $\mathrm{p} 65$ and YB-1, further experiments were performed with p65 deletion mutants (Fig. 9). We observed that a truncated version of $\mathrm{p} 65$, lacking both the rel homology domain and the IкB-binding domain (amino acids 1 to 298), activated expression from the pCAT-D construct but was unable to significantly affect the expression from the pCAT-кB construct (Fig. 9B, line 4). These data suggest that this truncated $\mathrm{p} 65$ acts in a dominant negative manner with respect to both the NF- $\mathrm{KB}$ site and the D domain. Interestingly, in the presence of this dominant negative p65 construct, YB-1 is able to enhance the expression from the pCAT-D construct (Fig. 9C, line 2). Furthermore, the presence of the dominant negative p65 construct abrogated the ability of YB-1 to affect expression from the pCAT-кB construct (Fig. 9C, line 2). Put together, these data support our model of regulation of the JC promoter by NF- $\mathrm{kB} / \mathrm{rel}$ subunits.

\section{DISCUSSION}

We examined the paradigm of NF- $\mathrm{kB} / \mathrm{rel}$ in the context of $\mathrm{JC}$ virus and observed an interesting dual and reciprocal regulation. We have demonstrated the presence of two NF-кB/ rel-responsive regions on the viral promoter, a bona fide consensus NF-кB site and the D domain. The constitutive NF-кB/ rel subunits, p50 and p52, negatively regulate expression from JC promoter constructs $\left(\mathrm{pJCV}_{\mathrm{L}}, \mathrm{pCAT- \kappa B}\right)$ containing the NF- $\mathrm{KB}$ site and positively regulate the transcription of JC promoter constructs $\left(\mathrm{pJCV}_{\mathrm{L} \Delta \kappa \mathrm{B}}, \mathrm{pCAT}-\mathrm{D}\right)$ containing the D do- main. A reciprocal pattern can be seen for the inducible subunit, p65, with activation of promoters containing the NF- $\mathrm{\kappa B}$ site and repression of promoters containing the $\mathrm{D}$ domain. The dual regulation of JC virus by NF- $\mathrm{KB} / \mathrm{rel}$ subunits is independent of the orientation of the viral promoter or of the presence of the viral transactivator protein, the large $\mathrm{T}$ antigen, or of the cell type (unpublished observations). Furthermore, the constitutive and inducible subunits tend to act in a mutually antagonistic manner with regard to either site on the viral promoter.

Our data presented here suggest that a D-domain-binding protein, YB-1, interacts with p65 with functional consequences. p65 may repress transcription from the $\mathrm{D}$ domain via direct interaction with the $\mathrm{D}$ domain or, indirectly, via interaction with YB-1. p50-mediated activation of the D domain may be a consequence of its ability to titrate p65 away from potential interactions with either YB-1 or the D domain itself. This proposed mechanism supports previous dissectional studies that revealed no potential transactivational domains within p50 and p52 $(6,8,50)$.

YB-1 exhibits the ability to modulate both basal and activated levels of transcription of $\mathrm{pJCV}_{\mathrm{L}}$ through the NF-кB site. These data point to a potential role for YB-1 as a transcriptional coactivator for the regulation of transcription from a NF-кB site. On the other hand, the inability of increasing concentrations of YB-1 alone to significantly affect transcription from the $\mathrm{D}$ domain may reflect the unchanged ratios of the NF- $\mathrm{KB}$ subunits in the vicinity of the D domain.

Pieced together, these data can be assembled into the model illustrated in Fig. 10. The basal state contains both p50 and p65 in the nucleus, allowing for various combinations of NF- $\mathrm{kB}$ dimers, including p50-p50 homodimers, p50-p65 heterodimers, and the occasional p65-p65 homodimers. Each dimer can potentially interact with the NF- $\mathrm{KB}$ site, and their collective influence accounts for the basal transcriptional level from this site (Fig. 10A, upper diagram). YB-1 could also play a role in basal levels of NF-kB driven transcription by its influence on p65 interaction with the NF- $\mathrm{BB}$ site. On the other hand, p65 attenuates the binding of YB-1 to the D domain. The effective level of basal transcription from the D domain is thus a consequence of YB-1 as well as its interaction with p65 (Fig. 10A, lower diagram).

Excess p50 alters the combinatorial dimerization of subunits in favor of predominantly p50-p50 homodimers and the occasional p50-p65 heterodimer. p50 homodimers are comparatively poor transactivators and thus may account for the decrease in basal transcription from the NF-кB site (Fig. 10B, upper diagram). On the other hand, the preponderance of $\mathrm{p} 50$ creates a relative dearth of $\mathrm{p} 65$ homodimers in the vicinity of the D domain. YB-1, in the absence of the disrupting influence of p65, could account for the increased transcription from the D domain (Fig. 10B, lower diagram).

Excess p65 alters the combinatorial dimerization of subunits in favor of p50-p65 heterodimers and p65-p65 homodimers $(10,16)$. The abundance of p65-maintaining dimers ensures the interaction of the powerful p65 transactivational domain with DNA and causes the increase in the basal transcription from the NF-кB site (Fig. 10C, upper diagram). p65 homodimers further increase the transcription from the NF- $\mathrm{KB}$ site by virtue of their increased DNA affinity upon interaction with YB-1. On the other hand, the surplus of p65 increases the likelihood of a YB-1-p65 interaction. In addition, p65 at high concentrations could bind to the D domain and account for the decreased transcription from the D domain (Fig. 10C, lower diagram).

The ability of the NF- $\mathrm{B} / \mathrm{rel}$ subunits to modulate transcrip- 

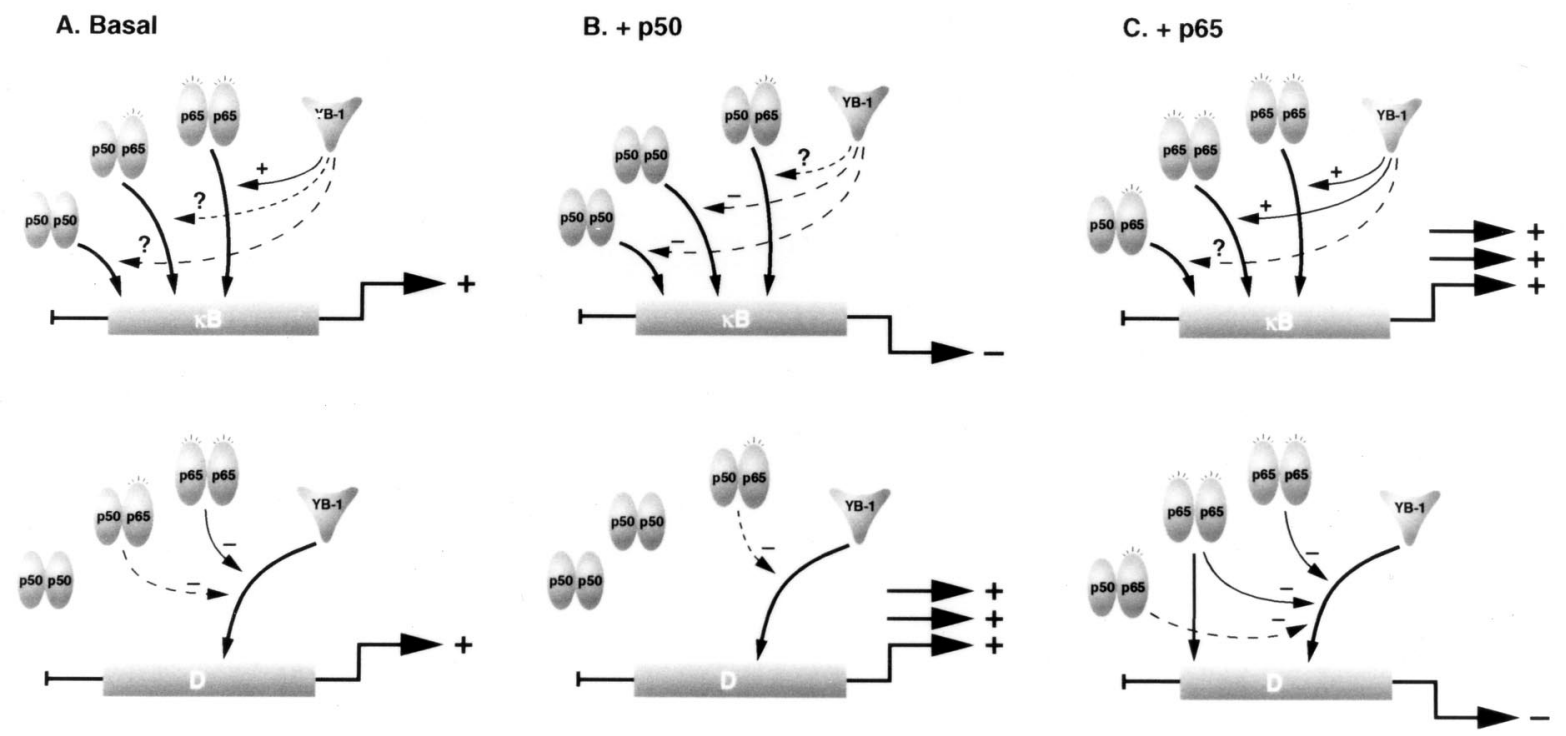

FIG. 10. Model for the regulation of the JC virus promoter by NF- $\mathrm{kB} / \mathrm{rel}$ subunits. The top half of each panel represents transcriptional control from the NF- $\mathrm{kB}$ site, while the bottom half represents the control of transcription from the D domain. Potential interactions between the various proteins and the specific DNA site are depicted by thicker arrows. Protein-protein interactions are depicted by slimmer arrows, with + and - representing a positive or a negative effect, respectively. The net transcriptional activity from a minimal promoter containing the binding sites is depicted by the arrow at the far right end of each schematic.

tion from the D domain led us to investigate whether a similar scenario was under way with another YB-1-binding site on the $\mathrm{JC}$ promoter, the B domain. We found that p50 and p52 increased transcription from a minimal promoter containing multiple copies of the B domain cloned upstream of a CAT reporter gene. The extent of activation and repression was reproducibly less pronounced (1.5- to 2-fold) with reporter constructs containing only one copy of the B domain. However, a more noticeable effect (3.5- to 5-fold) was seen with constructs containing multiple copies (three or more) of the B domain cloned upstream of the CAT reporter gene (data not shown). Perhaps the D domain represents a more optimal site for the interaction between YB-1 and the NF- $\mathrm{KB} / \mathrm{rel}$ subunits.

The choice of YB-1 as a target for p65 is intriguing. The $\mathrm{C}$ terminus of p65 may be involved in p65-YB-1 protein-protein interaction, because a deletion of this region results in a transdominant negative construct. The alternating acidic basic regions at the $\mathrm{N}$ terminus of $\mathrm{YB}-1$ represent the most likely domain of YB-1 involved in protein-protein interactions (47). Our analysis with deletions of YB-1 indicates that this may indeed be the case (unpublished observations). Some members of YB-1 have a dual function: regulation of transcription by binding to DNA in the nucleus (44) and regulation of translation by binding to mRNA in the cytoplasm. Recently, a member of the YB-1 family has been shown to be one of the major proteins of messenger ribonucleoprotein particles (13). YB-1 has been shown to have both a nuclear and cytoplasmic localization in eukaryotic cells (47). The dual localization of YB-1 and the NF- $\kappa$ B subunits may allow for interactions in both the nucleus and the cytoplasm or in transit between these subcellular compartments. The complex paradigm of NF- $\kappa \mathrm{B}$, with its multiple levels of regulation, potentially provides the cell with an exquisite control mechanism over both constitutive and induced NF- $\kappa \mathrm{B}$ activity.

The implications of this dual regulation of the JC virus lytic cycle deserve close scrutiny. The D domain contains the transcription initiation start site of many of the late viral RNA species, yet there is no consensus TATA box or initiator site that drives transcription from this site (1). The basal (uninduced) transcription of the viral late promoter is positively regulated by $\mathrm{p} 50 / \mathrm{p} 52$ via the $\mathrm{D}$ domain, whereas induced transcription is positively regulated by $\mathrm{p} 65$ via the $\mathrm{NF}-\kappa \mathrm{B}$ site. These data suggest that stimulation with specific agents could induce a switch in the determinant of viral gene expression from the D domain to the NF- $\mathrm{KB}$ site, as a functional consequence of altered stoichiometric ratios of the NF- $\mathrm{B}$ subunits. Viruses with mutations in the NF- $\mathrm{NB}$ site may still be regulated by $\mathrm{NF}-\kappa \mathrm{B} / \mathrm{rel}$ subunits and may offer the virus an important backup route for expression in the absence of exogenous stimuli.

\section{ACKNOWLEDGMENTS}

We express our gratitude to the past and present members of the Molecular Neurovirology Section of the Jefferson Institute of Molecular Medicine for their unflagging support, insightful discussions, and invaluable materials. The NF-kB eukaryotic expression plasmids were obtained through the AIDS Research and Reference Reagent Program, Division of AIDS, NIAID, NIH, from Gary Nabel and Neil Perkins. We thank Charles Kunsch for the prokaryotic NF-кB expression plasmids (and Dean Ballard for the p65 mutant expression constructs) used in this study. We thank the members of the laboratory of J. P. Ting for their generous supply of YB-1 antiserum. We also thank Marina Hoffman for critical reading of the manuscript and Cynthia Schriver for its preparation.

This work was supported by a grants from NCI and NINDS (NIH) awarded to K.K.

\section{REFERENCES}

1. Ahmed, S., M. Chowdhury, and K. Khalili. 1990. Regulation of a human neurotropic virus promoter, $\mathrm{JCV}_{\mathrm{E}}$ : identification of a novel activator domain located upstream from the $98 \mathrm{bp}$ enhancer promoter region. Nucleic Acids Res. 18:7417-7423.

2. Askamit, A., and J. Proper. 1988. JC virus replicates in primary adult astrocytes in culture. Ann. Neurol. 24:471.

3. Astrom, K. E., E. L. Mancall, and E. P. Richardson. 1958. Progressive multifocal leukoencephalopathy. Brain 81:93-127.

4. Baeuerle, P. A., and T. Henkel. 1994. Function and activation of NF-кB in the immune system. Annu. Rev. Immunol. 12:141-179.

5. Beg, A. A., and A. S. Baldwin, Jr. 1993. The I kappa B proteins: multifunc- 
tional regulators of rel/NF-kappa B transcription factors. Genes Dev. 7:2064-2070.

6. Bressler, P., K. Brown, W. Timmer, V. Bours, U. Siebenlist, and A. S. Fauci. 1993. Mutational analysis of the p50 subunit of NF-kB and inhibition of NF- B activity by trans-dominant p50 mutants. J. Virol. 67:288-293.

7. Chen, N. N., C. F. Chang, G. L. Gallia, D. A. Kerr, E. M. Johnson, C. P. Krachmarov, S. M. Barr, R. J. Frisque, B. Bollag, and K. Khalili. 1995. Cooperative action of cellular proteins YB-1 and Pur $\alpha$ with the tumor antigen of the human JC polyomavirus determines their interaction with the viral lytic control element. Proc. Natl. Acad. Sci. USA 92:1087-1091.

8. Coleman, T. A., C. Kunsch, M. Maher, S. M. Ruben, and C. A. Rosen. 1993. Acquisition of NF- $\mathrm{KB} 1$-selective DNA binding by substitution of four amino acid residues from NF-кB1 into RelA. Mol. Cell. Biol. 13:3850-3859.

9. Didier, D., J. Schiffenbauer, S. Woulfe, M. Zacheis, and B. Schwartz. 1988. Characterization of the cDNA encoding a protein binding to the major histocompatibility complex class II Y box. Proc. Natl. Acad. Sci. USA 85: $7322-7326$.

10. Diehl, J. A., W. Tong, G. Sun, and M. Hannink. 1995. Tumor necrosis factor-alpha-dependent activation of a RelA homodimer in astrocytesincreased phosphorylation of RelA and mad-3 precede activation of RelA. J. Biol. Chem. 270:2703-2707.

11. Dignam, J. D., R. M. Lebowitz, and R. G. Roeder. 1983. Accurate transcription initiation by RNA polymerase II in a soluble extract from mammalian nuclei. Nucleic Acids Res. 11:1475-1489.

12. Dobrzanski, P., R. P. Ryseck, and R. Bravo. 1994. Differential interactions of rel-NF-кB complexes with IкBa determine pools of constitutive and inducible NF-кB activity. EMBO J. 13:4608-4616.

13. Evdokimova, V. M., C.-L. Wei, A. S. Sitikov, P. N. Simenenko, O. A. Lazarev, K. S. Vasilenko, V. A. Ustinov, J. W. B. Hershey, and L. P. Ovchinnikov. 1995. The major protein of messenger ribonucleoprotein particles in somatic cells is a member of the Y-box binding transcription factor family. J. Biol. Chem. 270:3186-3192.

14. Frisque, R. J., and F. A. White. 1992. The molecular biology of JC virus, causative agent of progressive multifocal leukoencephalopathy, p. 25-158. In R. P. Roos (ed.), Molecular Neurovirology. Humana Press, Towana, N.J.

15. Fujita, T., G. P. Nolan, S. Ghosh, and D. Baltimore. 1992. Independent modes of transcriptional activation by the $\mathrm{p} 50$ and p 65 subunits of NF-KB. Genes Dev. 6:775-787.

16. Ganchi, P. A., S. Sun, W. C. Greene, and D. W. Ballard. 1993. A novel NF-кB complex containing p65 homodimers: implications for transcriptional control at the level of subunit dimerization. Mol. Cell. Biol. 13:7826-7835.

17. Gilmore, T. D., and P. J. Morin. 1993. The IкB proteins: members of a multifunctional family. Trends Genet. 9:427-433.

18. Gorman, C. M., L. F. Moffat, and B. H. Howard. 1982. Recombinant genomes which express chloramphenicol acetyltransferase in mammalian cells. Mol. Cell. Biol. 2:1044-1051.

19. Graham, F. L., and A. J. van der Eb. 1973. A new technique for the assay of infectivity of human adenovirus 5 DNA. Virology 52:456-467.

20. Grimm, S., and P. A. Baeuerle. 1993. The inducible transcription factor NF- $\mathrm{B}$ structure-function relationship of its protein subunits. Biochemistry 290:297-308.

21. Kerr, D., C.-F. Chang, N. N. Chen, G. Gallia, G. Raj, B. Schwartz, and K. Khalili. 1994. Transcription of a human neurotropic virus promoter in glial cells: effect of YB-1 on expression of JC viral late gene. J. Virol. 68:76377643.

22. Kerr, L. D., L. J. Ransone, P. Wamsley, M. J. Schmitt, T. G. Boyer, Q. Zhou, A. J. Berk, and I. Verma. 1993. Association between protooncoprotein rel and TATA-binding protein mediates transcriptional activation by NF-кB. Nature (London) 365:412-419.

23. Kolluri, R., T. Torrey, and A. Kinniburgh. 1992. A CT promoter element binding protein: definition of a double stranded and a novel single stranded DNA binding motif. Nucleic Acids Res. 20:111-116.

24. Kunsch, C., S. M. Ruben, and C. A. Rosen. 1992. Selection of optimal $\kappa B / R e l$ DNA-binding motifs: interaction of both subunits of NF-kB with DNA is required for transcriptional activation. Mol. Cell. Biol. 12:4412-4421.

25. LeClair, K. P., M. A. Blanar, and P. A. Sharp. 1992. The p50 subunit of NF-кB associates with the NF-IL6 transcription factor. Proc. Natl. Acad. Sci. USA 89:8145-8149.

26. Lernbecher, T., U. Muller, and T. Wirth. 1993. Distinct NF-кB/rel transcription factors are responsible for tissue-specific and inducible gene activation. Nature (London) 365:767-770

27. Major, E. O., K. Amemiya, C. S. Tornatore, S. A. Houff, and J. R. Berger. 1992. Pathogenesis and molecular biology of progressive multifocal leukoencephalopathy, the JC virus-induced demyelinating disease of the human brain. Clin. Microbiol. Rev. 5:49-73.
27a.Mayreddy, R. P. R., et al. Unpublished data.

28. Murakami, T., H. Hirai, T. Suzuki, J.-I. Fujisawa, and M. Yoshida. 1995 HTLV-1 Tax enhances NF-кB2 expression and binds to the products p52 and $\mathrm{p} 100$, but does not suppress the inhibitory function of p100. Virology 206:1066-1074

29. Padgett, B. L., D. L. Walker, G. M. Zu Rhein, R. J. Eckroade, and B. H Dessel. 1971. Cultivation of a papova-like virus from human brain with progressive multifocal leukoencephalopathy. Lancet i:1257-1260.

30. Perkins, N. D., R. M. Schmid, C. S. Duckett, K. Leung, N. R. Rice, and G. J. Nabel. 1992. Distinct combinations of NF-кB subunits determine the specificity of transcriptional activation. Proc. Natl. Acad. Sci. USA 89:1529-1533.

31. Raj, G. V., and K. Khalili. 1994. A novel rapidly inducible GGA/C-binding factor, GBP-i, regulates transcription from the JC virus promoter. Mol. Cell. Biol. 14:7770-7781.

31a.Raj, G. V., et al. Unpublished data.

32. Ranganathan, P., and K. Khalili. 1993. The transcriptional enhancer element, $\mathrm{\kappa B}$, regulates promoter activity of the human neurotropic virus, JCV in cells derived from the CNS. Nucleic Acids Res. 21:1959-1964.

33. Ray, A., and K. E. Prefontaine. 1994. Physical association and functional antagonism between the p65 subunit of transcription factor NF- $\mathrm{kB}$ and the glucocorticoid receptor. Proc. Natl. Acad. Sci. USA 91:752-756.

34. Ruben, S. M., J. F. Klement, T. A. Coleman, M. Maher, C.-H. Chen, and C. A. Rosen. 1992. I-rel: a novel rel-related protein that inhibits NF-кB transcriptional activity. Genes Dev. 6:745-760.

35. Schmid, R. M., S. Liptay, J. C. Betts, and G. J. Nabel. 1994. Structural and functional analysis of NF-kappa B. Determinants of DNA binding specificity and protein interaction. J. Biol. Chem. 269:32162-32167.

36. Schmid, R. M., N. D. Perkins, C. S. Duckett, P. C. Andrews, and G. J. Nabel. 1991. Cloning of an NF-кB subunit which stimulates HIV transcription in synergy with p65. Nature (London) 352:733-756.

37. Schmitz, M. L., and P. A. Baeuerle. 1991. The p65 subunit is responsible for the strong transcription activating potential of NF-кB. EMBO J. 10:38053817.

38. Schreiber, E., P. Matthias, M. M. Muller, and W. Schaffner. 1989. Rapid detection of octamer binding proteins with 'mini-extracts', prepared from a small number of cells. Nucleic Acids Res. 17:6419.

39. Sher, A., R. T. Gazzinelli, I. P. Oswald, M. Clerici, M. Kullberg, E. J. Pearce, J. A. Berzofsky, T. R. Mosmann, S. L. James, H. L. Morse, and G. M. Shearer. 1992. Role of T-cell derived cytokines in the downregulation of immune responses in parasitic and retroviral infections. Immunol. Rev. 127: 183-219.

40. Siebenlist, U., G. Franzoso, and K. Brown. 1994. Structure, regulation, and function of NF-кB. Annu. Rev. Cell Biol. 10:405-456.

41. Stein, B., A. S. Baldwin, Jr., D. W. Ballard, W. C. Greene, P. Angel, and P. Herrlich. 1993. Cross-coupling of the NF-кB p65 and Fos/Jun transcription factors produces potentiated biological function. EMBO J. 12:3879-3891.

42. Stein, B., P. C. Cogswell, and A. S. Baldwin, Jr. 1993. Functional and physical associations between NF- $\mathrm{BB}$ and C/EBP family members: a Rel domainbZIP interaction. Mol. Cell. Biol. 13:3964-3974.

43. Thanos, D., and T. Maniatis. 1995. NF-кB: a lesson in family values. Cell 80:529-532.

44. Ting, J. P., A. Painter, N. J. Zeleznik-Le, G. MacDonald, T. M. Moore, A. Brown, and B. D. Schwartz. 1994. YB-1 DNA-binding protein represses interferon gamma activation of class II major histocompatibility complex genes. J. Exp. Med. 179:1605-1611.

45. Tornatore, C., A. Nath, K. Amemiya, and E. O. Major. 1991. Persistent human immunodeficiency virus type 1 infection in human fetal glial cells reactivated by T-cell factor(s) or by cytokines tumor necrosis factor alpha and interleukin-1ß. J. Virol. 65:6094-6100.

46. Walker, D. L., and B. L. Padgett. 1983. The epidemiology of human papovaviruses, p. 99-106. In J. L. Sever and D. L. Madden (ed.), Polyomaviruses and human neurological diseases. Alan R. Liss, Inc., New York.

47. Wolffe, A. 1994. Structural and functional properties of the evolutionarily ancient Y-box family of nucleic acid binding proteins. Bioessays 16:245-251.

48. Wolffe, A., S. Tafuri, M. Ranjan, and M. Familari. 1992. The Y-box factors: a family of nucleic acid binding proteins conserved from Escherichia coli to man. New Biol. 4:290-298.

49. Xu, X., C. Prorock, H. Ishikawa, E. Maldonado, Y. Ito, and C. Gelinas. 1993 Functional interaction of the v-rel and c-rel oncoproteins with the TATAbinding protein and association with transcription factor IIb. Mol. Cell. Biol. 13:6733-6741.

50. Zhang, J., C. C. Chang, L. Lombardi, and R. Dalla-Favera. 1994. Rearranged NFKB2 gene in the HUT78 T-lymphoma cell line codes for a constitutively nuclear factor lacking transcriptional repressor functions. Oncogene 9:1931-1937. 